\title{
THE MARGIN OF EXPOSURE TO FORMALDEHYDE IN ALCOHOLIC BEVERAGES
}

\author{
Yulia B MONAKHOVA ${ }^{1,2}$, Julien A JENDRAL ${ }^{2}$, and Dirk W LACHENMEIER ${ }^{2}$ \\ Department of Chemistry, Saratov State University, Saratov, Russia ${ }^{1}$, Chemisches und Veterinäruntersuchungsamt \\ (CVUA) Karlsruhe, Karlsruhe, Germany²
}

Received in January 2012

CrossChecked in June 2012

Accepted in June 2012

\begin{abstract}
Formaldehyde has been classified as carcinogenic to humans (WHO IARC group 1). It causes leukaemia and nasopharyngeal cancer, and was described to regularly occur in alcoholic beverages. However, its risk associated with consumption of alcohol has not been systematically studied, so this study will provide the first risk assessment of formaldehyde for consumers of alcoholic beverages.

Human dietary intake of formaldehyde via alcoholic beverages in the European Union was estimated based on WHO alcohol consumption data and literature on formaldehyde contents of different beverage groups (beer, wine, spirits, and unrecorded alcohol). The risk assessment was conducted using the margin of exposure (MOE) approach with benchmark doses (BMD) for $10 \%$ effect obtained from dose-response modelling of animal experiments.

For tumours in male rats, a BMD of $30 \mathrm{mg} \mathrm{kg}^{-1}$ body weight per day and a "BMD lower confidence limit" (BMDL) of $23 \mathrm{mg} \mathrm{kg}^{-1} \mathrm{~d}^{-1}$ were calculated from available long-term animal experiments. The average human exposure to formaldehyde from alcoholic beverages was estimated at $8 \cdot 10^{-5} \mathrm{mg} \mathrm{kg}^{-1} \mathrm{~d}^{-1}$. Comparing the human exposure with BMDL, the resulting MOE was above 200,000 for average scenarios. Even in the worst-case scenarios, the MOE was never below 10,000, which is considered to be the threshold for public health concerns.

The risk assessment shows that the cancer risk from formaldehyde to the alcohol-consuming population is negligible and the priority for risk management (e.g. to reduce the contamination) is very low. The major risk in alcoholic beverages derives from ethanol and acetaldehyde.
\end{abstract}

KEY WORDS: alcohol, alcohol consumption, aldehydes, cancer, risk assessment

Formaldehyde (methanal, $\mathrm{CH}_{2} \mathrm{O}$, CAS \# 50-00-0) is a colourless substance, which is widely present in foods, industry, and in the environment $(1,2)$ and may also be endogenously produced in humans and animals (3). The industrial use includes mainly the production of various types of resin, the use as intermediate in the manufacture of industrial chemicals, and the direct use in aqueous solutions (formalin) as a disinfectant and preservative (1-3). Epidemiological studies have demonstrated a causal relationship between formaldehyde and cancer in humans (3). Causality is indicated by consistent findings of increased risks of nasopharyngeal cancer, sinonasal cancer, and myeloid leukaemia among individuals with high exposure to formaldehyde. The findings are based on case-control studies of industrial workers and other professional groups in inhalatory contact with formaldehyde such as pathologists, funeral directors or embalmers (3). Biological mechanisms associated with formaldehydeinduced cancer are not completely understood, but potential carcinogenic modes of actions for formaldehyde include DNA reactivity (covalent 
binding), gene mutation, chromosomal breakage, aneuploidy, and epigenetic effects (3). However, the biological plausibility of an association between formaldehyde exposure and leukaemia was questioned, because formaldehyde is rapidly metabolised, and it would not be expected to enter the systemic circulation (3). No studies in humans are available for the oral route of exposure, but animal feeding experiments have demonstrated that formaldehyde may also be carcinogenic after ingestion $(4,5)$.

The hazard of formaldehyde has been confirmed by the International Agency for Research on Cancer (IARC), which found sufficient evidence for the carcinogenicity of formaldehyde both for humans and experimental animals. The IARC cancer classification was upgraded in 2006 and formaldehyde was assigned to group 1 ("carcinogenic to humans") with clear evidence for cancer in humans $(5,6)$.

Formaldehyde is a natural constituent in a variety of fruits, vegetables, meat, milk products, and fish (1). Feron et al. (1) estimated that the formaldehyde intake from food ranges between $1.5 \mathrm{mg}$ and $14 \mathrm{mg}$ per person per day, which may already reach the reference dose (RfD) for chronic oral exposure of $0.2 \mathrm{mg} \mathrm{kg}^{-1}$ $\mathrm{d}^{-1}$ (approximately $12 \mathrm{mg} \mathrm{d}^{-1}$ for a $60-\mathrm{kg}$ adult) postulated by the US Environmental Protection Agency (EPA) (7). Relatively high concentrations of formaldehyde were found in alcoholic beverages; for example, in sugar cane spirits (mean $4.13 \mathrm{mg} \mathrm{L}^{-1}$, maximum $10.90 \mathrm{mg} \mathrm{L}^{-1}$ ) (8) and rum (mean $2.42 \mathrm{mg}$ $\mathrm{L}^{-1}$, maximum $10.07 \mathrm{mg} \mathrm{L}^{-1}$ ) (9). In our on-going investigation of the composition and global public health impact of alcoholic beverages, including unrecorded alcohol (10), we have also detected high formaldehyde concentrations in a number of products (11). Thus, the natural occurrence of formaldehyde from methanol oxidation in alcohol products, together with contamination from other sources (e.g. the usage of formaldehyde-containing or formaldehydereleasing disinfectants), could therefore be a potential problem on a worldwide scale.

In contrast to other constituents of alcoholic beverages (e.g. methanol, higher alcohols, acetaldehyde or ethyl carbamate), for which excellent risk assessments are available in the literature (12-15), we found a major knowledge gap regarding information about the potential public health impact of formaldehyde, resulting in an inability to adequately ascertain the risk for consumers of the alcoholic beverages researched. In this study, applying the harmonised approach of the European Food Safety
Authority (EFSA) (16), we present for the first time, a quantitative risk assessment for formaldehyde in alcoholic beverages.

\section{METHODS}

Data on formaldehyde were obtained by a computer-assisted literature search. Searches were carried out in the following databases: PubMed, Toxnet, and ChemIDplus (US National Library of Medicine, Bethesda, MD), Web of Science (Thomson Scientific, Philadelphia, PA), and IPCS/INCHEM (International Programme on Chemical Safety/ Chemical Safety Information from Intergovernmental Organizations, WHO, Geneva, Switzerland). We specifically aimed to identify long-term animal studies that would be usable for dose-response modelling as well as studies on the occurrence of formaldehyde in alcoholic beverages.

Analysis was conducted according to the harmonised approach of EFSA (16) and similar to our previous acetaldehyde cancer risk assessment (14). This includes an approach known as the margin of exposure (MOE). MOE is defined as the ratio between the benchmark dose (BMD) and the estimated human intake of the same compound. MOE can be used to compare the health risk of different compounds and prioritise risk management actions. By definition, the lower the MOE, the larger the risk for humans; generally a value under 10,000 is used to define public health risks (16). The benchmark dose (BMD), derived from animal data by mathematical modelling within the observed range of experimental data, was used as a reference point. To obtain MOE, the Benchmark Dose Lower Confidence Limit (BMDL) for a $10 \%$ effect was taken (MOE $=$ BMDL / Exposure). BMDL is an estimate of the lowest dose that is $95 \%$ certain to cause no more than a $10 \%$ effect (e.g. cancer incidence) in rodents. The BMD and BMDL values were calculated using the US EPA's BMDS 2.2 software (available at the US Environmental Protection Agency website: http://www.epa.gov/ncea/bmds/ index.html).

\section{RESULTS}

Toxicity of orally ingested formaldehyde in animal studies

There is adequate evidence for the carcinogenicity of formaldehyde in animal experimental studies (6). 
Several studies have proved that long-term inhalation exposure to formaldehyde causes both benign and malignant nasal tumours in male and female rats (1719). As the focus on the specific effects of orally administered formaldehyde is relatively new, there are not many studies on this subject. The following two are considered to be the most significant ones: Soffriti et al. (4) conducted a long-term study of rat groups exposed to formaldehyde that resulted in a carcinogenic effect; Til et al. (20) observed severe damage to the gastric mucosa, renal papillary necrosis, and irregular mucosal thickening in the forestomach and/or glandular stomach in rats given top doses of formaldehyde. These studies are discussed in more detail in the section "dose response analysis".

Besides these two pivotal studies, some further studies were identified. In the paper of Tobe et al. (21), groups of 20 male and 20 female Wistar rats were given formaldehyde in their drinking water at four concentrations $(0.50,0.10,0.02$, and 0$) \%$ for 24 months. Various non-neoplastic lesions, erosions, and ulcers were found both in the forestomach and glandular stomach mostly in the $0.50 \%$ group. There were no significant differences in the incidence of any tumours among groups of both sexes. Based on their results, the no observable effect level of formaldehyde was $0.02 \%$ in drinking water $\left(10 \mathrm{mg} \mathrm{kg}^{-1} \mathrm{~d}^{-1}\right)$. Another valuable oral study is that of Takahasi et al. (22), in which Wistar rats were given formaldehyde during a 32 -week period at a single concentration level $(0.5 \%$ - about $300 \mathrm{mg} \mathrm{kg}^{-1} \mathrm{bw}$ per day). Due to the single dose level and/or limited number of animals, these studies were not included in our dose-responsemodelling. However, it is important to mention that although no tumours were observed, papillomas in the forestomach and non-neoplastic changes in glandular stomach were reported (22). The finding suggests that formaldehyde could exert pre-carcinogenic activity in the rat glandular stomach. Long-term or lifetime studies above certain concentration threshold are necessary for detecting tumours (4).

\section{Dose-response analysis}

There is no adequate human study available for a dose-response analysis. From the animal experiments mentioned above, two long-term studies of the oral route of exposure to formaldehyde appear to be suitable for dose-response modelling.

Til et al. (20) examined the oral toxicity of formaldehyde in rats in a two-year drinking-water study at dose levels of $(0,1.2,15$, and 82$) \mathrm{mg} \mathrm{kg}^{-1} \mathrm{~d}^{-1}$ for males and $(0,1.8,21$, and 109$) \mathrm{mg} \mathrm{kg}^{-1} \mathrm{~d}^{-1}$ for females. The study did not provide any evidence of carcinogenicity of formaldehyde after oral consumption. Thickening and raising of the limiting ridge of the forestomach, irregular mucosal thickenings, histopathological gastric changes (papillary epithelial hyperplasia, hyperkeratosis, focal ulceration, and focal chronic atrophic gastritis) were observed mostly in the high-dose group. In a more recent 104-week study of carcinogenicity by Soffritti et al. (4), male and female Sprague-Dawley rats were given drinking water containing formaldehyde at concentrations of about $\left(0,1,5,10,51,102\right.$, and 153) $\mathrm{mg} \mathrm{kg}^{-1} \mathrm{~d}^{-1}$ [own calculations based on formaldehyde concentrations in drinking water $(0,10,50,100,500,1000$, and 1500) $\mathrm{mg} \mathrm{L}^{-1}$ and data about average body weight and drinking volume]. Treatment with formaldehyde resulted in an increase in total malignant tumours and showed specific carcinogenic effects on various organs and tissues.

Due to the lower number of animal subjects and smaller doses, Til et al. (20) provided only limited applicable evidence for dose-response assessments, especially as carcinogenic effects were not detectable. However, we modelled this study for comparison purposes, as irregular thickenings in the forestomach and glandular stomach, chronic atrophic gastritis, and histopathological changes (papillary epithelial hyperplasia accompanied by hyperkeratosis) could be pre-carcinogenic lesions. A large number of oncological lesions of the intestine and the stomach were detected in the study of Soffritti et al. (4), especially at the highest doses (which were higher than the ones used in Til et al. (20)). The study by Soffritti et al. (4) is, therefore, the only study adequately designed to be used for a dose-response assessment of carcinogenic effects of orally administered formaldehyde.

The best-fitting models for different end-points are listed in Table 1. It can be seen that the values for different end-points calculated from the Til et al. (20) study are consistent: the BMD and BMDL values are in the range of (22 to 50$) \mathrm{mg} \mathrm{kg}^{-1} \mathrm{~d}^{-1}$ and (12 to 45) $\mathrm{mg} \mathrm{kg}^{-1} \mathrm{~d}^{-1}$, respectively. Regarding the Soffritti et al. data (4), significant models were reached for both sexes when the total number of tumour-bearing animals was modelled. An adequate model for hemolymphoreticular neoplasias (females) was also observed (Table 1). Overall, BMDs and BMDLs of models from both studies $(4,20)$ are in the same order of magnitude, which is indicative of an overall adequacy of the calculated values, as even between 
Table 1 Summary of own dose response modelling results for formaldehyde in different animal experiments conducted by Til et al. (20) and Soffritti et al. (4)

\begin{tabular}{|c|c|c|c|c|c|}
\hline End-point & & Model $^{\mathrm{a}}$ & p-value ${ }^{b}$ & $\begin{array}{c}\mathrm{BMD}^{\mathrm{c}} / \\
\mathrm{mg} \mathrm{kg}^{1} \mathrm{~d}^{-1}\end{array}$ & $\begin{array}{l}\mathrm{BMDL}^{\mathrm{d}} / \\
\mathrm{mg} \mathrm{kg}^{1} \mathrm{~d}^{-1}\end{array}$ \\
\hline \multicolumn{6}{|l|}{ Til et al. (20) } \\
\hline \multirow{3}{*}{$\begin{array}{l}\text { Focal papillary epithelial } \\
\text { hyperplasia }\end{array}$} & Male & Gamma & 0.77 & 41 & 18 \\
\hline & Female & Multistage & 0.42 & 29 & 22 \\
\hline & Combined & Dichotomous-Hill & 0.49 & 25 & 21 \\
\hline \multirow{3}{*}{ Focal hyperkeratosis } & Male & Multistage-Cancer & 0.28 & 34 & 12 \\
\hline & Female & Multistage-Cancer & 0.43 & 34 & 21 \\
\hline & Combined & Multistage & 0.55 & 45 & 26 \\
\hline \multirow{3}{*}{ Chronic atrophic gastritis } & Male & Gamma & $(1)^{\mathrm{e}}$ & $(38)$ & $(21)$ \\
\hline & Female & Gamma & $(1)^{e}$ & (38) & (24) \\
\hline & Combined & Gamma & $(1)^{\mathrm{e}}$ & (38) & (28) \\
\hline \multirow{3}{*}{ Focal ulceration } & Male & Gamma & $(1)^{\mathrm{e}}$ & $(70)$ & (38) \\
\hline & Female & Gamma & $(1)^{\mathrm{e}}$ & $(95)$ & $(55)$ \\
\hline & Combined & LogProbit & 0.85 & 62 & 45 \\
\hline \multirow{3}{*}{ Gradular hyperplasia } & Male & Multistage-Cancer & 0.24 & 37 & 25 \\
\hline & Female & Gamma & $(1)^{\mathrm{e}}$ & (90) & (49) \\
\hline & Combined & Dichotomous-Hill & 0.78 & 41 & 23 \\
\hline \multirow{3}{*}{ Papillary necrosis } & Male & Logistic & 0.38 & 36 & 29 \\
\hline & Female & Multistage-Cancer & 0.24 & 50 & 36 \\
\hline & Combined & Quantal Linear & 0.11 & 22 & 17 \\
\hline \multicolumn{6}{|l|}{ Soffritti et al. (4) } \\
\hline \multirow{2}{*}{ Tumour-bearing animals } & Male & Probit & 0.13 & 30 & 23 \\
\hline & Female & Logistic & 0.59 & 67 & 38 \\
\hline \multirow{2}{*}{$\begin{array}{l}\text { Hemolymphoreticular } \\
\text { neoplasias }\end{array}$} & Male & Quantal Linear & $(0.036)^{f}$ & $(40)$ & $(28)$ \\
\hline & Female & Multistage-Cancer & 0.63 & 111 & 61 \\
\hline
\end{tabular}

${ }^{a}$ Data from best-fitting models selected with BMDS 2.2-software according to US EPA criteria are presented

${ }^{b}$ A p-value greater than 0.1 indicates that the model fits the data ( $p$-value $1.0=$ perfect fit).

${ }^{c} B M D$ : benchmark dose for a $10 \%$ incidence of health effect

${ }^{d} B M D L:$ lower one-sided confidence limit of the BMD

e Only the highest dose-level exhibited effects. No clear dose-response established. Values are shown in brackets for information

${ }^{f}$ Not significant dose-response. Values are shown in brackets for information

different models differences up to factors of five are accepted as typical and would allow for an averaging of the values (23). To be conservative, we decided to take the model for male tumour-bearing animals with a BMD of $30 \mathrm{mg} \mathrm{kg}^{-1} \mathrm{~d}^{-1}$ and a BMDL of $23 \mathrm{mg}$ $\mathrm{kg}^{-1} \mathrm{~d}^{-1}$ for our further calculations (Figure 1). Notably, these values are expectedly smaller than what we calculated for acetaldehyde from the same Soffritti et a1. (4) study $\left(B M D=114 \mathrm{mg} \mathrm{kg}^{-1} \mathrm{~d}^{-1}\right.$ and $\left.\mathrm{BMDL}=56 \mathrm{mg} \mathrm{kg}^{-1} \mathrm{~d}^{-1}\right)$ (14). This is consistent with previous assumptions that the toxicity of aldehydes decreases with chain length (24).

\section{Exposure assessment}

In this study we used the EFSA guidelines (16), which recommend that risk assessments provide different exposure scenarios (e.g. for entire, or specific groups of populations) along with their inherent uncertainties. Other than the mean and median, intakes from highly exposed individuals (due to high consumption of average contaminated foods or to average consumption of highly contaminated foods) should be considered as represented by the $90^{\text {th }}, 95^{\text {th }}$, $97.5^{\text {th }}$, and $99^{\text {th }}$ percentiles.

To provide estimates on the dietary intake of formaldehyde, data on the consumption of alcoholic 


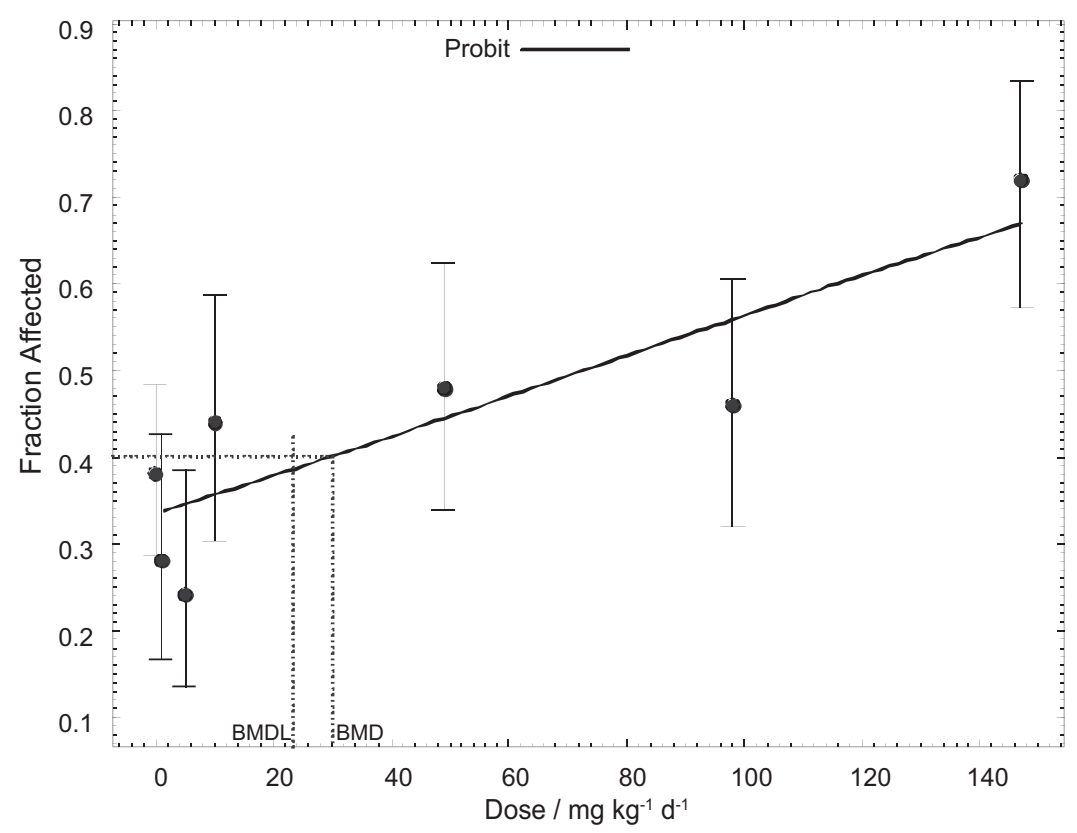

Figure 1 Benchmark dose modelling for oral formaldehyde administration with male tumour-bearing animals as endpoint. Probit model with 0.95 confidence level. BMD: benchmark dose for a $10 \%$ incidence of health effect; BMDL: lower one-side confidence limit of the BMD. Original data from Soffritti et al. (4).

beverages and their content of formaldehyde is needed. Currently, there are not enough systematic data on formaldehyde content of alcoholic beverages or indeed of most foods in general. Although formaldehyde is a natural component of a variety of foodstuffs (1), with the highest concentrations in fruits (25), vegetables
(25), and fish (26-28), monitoring has generally been sporadic and inconsistent.

Nevertheless, there are some studies where the actual formaldehyde content in different alcoholic beverages was determined $(8,9,11,29-48)$. The investigation of alcoholic beverages for formaldehyde

Table 2 Formaldehyde concentration in alcoholic beverages

\begin{tabular}{|c|c|c|c|c|c|c|c|c|c|}
\hline \multirow[t]{2}{*}{ Category $^{a}$} & \multirow{2}{*}{$\begin{array}{l}\text { Sample } \\
\text { size }\end{array}$} & \multicolumn{7}{|c|}{ Formaldehyde / $\mathrm{mg} \mathrm{L}^{-1}$ (data summarised from Refs. 8, 9, 11, 29-48) } & \multirow{2}{*}{$\begin{array}{l}>2.6 \mathrm{mg} \\
\mathrm{L}^{-1 \mathrm{~b} / \%}\end{array}$} \\
\hline & & Mean & Median & $\begin{array}{c}90^{\text {th }} \\
\text { percentile }\end{array}$ & $\begin{array}{c}95^{\text {th }} \\
\text { percentile }\end{array}$ & $\begin{array}{c}97.5^{\text {th }} \\
\text { percentile }\end{array}$ & $\begin{array}{c}99^{\text {th }} \\
\text { percentile }\end{array}$ & Maximum & \\
\hline Rum/cane & 86 & 0.42 & 0.06 & 0.48 & 2.20 & 3.08 & 7.33 & 10.90 & 6.98 \\
\hline Whiskey & 29 & 0.26 & 0.08 & 0.72 & 1.19 & 1.43 & 1.54 & 1.62 & 0.00 \\
\hline White spirits & 139 & 0.01 & 0.00 & 0.01 & 0.01 & 0.06 & 0.11 & 0.80 & 0.00 \\
\hline $\begin{array}{l}\text { White spirits incl. } \\
\text { tequila }\end{array}$ & 177 & 0.27 & 0.00 & 0.83 & 1.72 & 2.69 & 3.24 & 6.06 & 5.08 \\
\hline Flavoured spirits & 106 & 0.24 & 0.00 & 0.45 & 0.95 & 1.43 & 2.70 & 5.39 & 1.89 \\
\hline Asian products & 43 & 1.23 & 0.03 & 1.54 & 9.75 & 13.44 & 14.06 & 14.37 & 9.30 \\
\hline Brandy & 19 & 0.69 & 0.18 & 2.06 & 2.24 & 2.62 & 2.86 & 3.01 & 15.79 \\
\hline Beer & 93 & 0.02 & 0.00 & 0.05 & 0.17 & 0.21 & 0.23 & 0.27 & 0.00 \\
\hline Wine & 39 & 0.2 & 0.02 & 0.72 & 0.82 & 0.89 & 1.05 & 1.15 & 0.00 \\
\hline $\begin{array}{l}\text { Unrecorded } \\
\text { and others }\end{array}$ & 116 & 0.32 & 0.00 & 1.04 & 1.53 & 3.05 & 3.47 & 6.71 & 4.31 \\
\hline Total spirits & 417 & 0.31 & 0.01 & 0.82 & 1.70 & 2.84 & 3.32 & 10.90 & 4.80 \\
\hline $\begin{array}{l}\text { Total all alcoholic } \\
\text { beverages }\end{array}$ & 708 & 0.32 & 0 & 0.74 & 1.54 & 2.93 & 6.01 & 14.37 & 4.10 \\
\hline
\end{tabular}

a The categories were chosen based on available consumption data (see Lachenmeier et al. (14) for details)

${ }^{b}$ A tolerable concentration of $2.6 \mathrm{mg} \mathrm{L} \mathrm{L}^{-1}$ was suggested by WHO IPCS (2) based on non-cancer endpoints 
content started as early as in 1983 with the measurement of a limited number $(n=9)$ of beer samples (29). From then, formaldehyde has also been detected in wine, spirits, and unrecorded alcohol. However, most of the studies evaluated only a limited number of samples. Up to now, the only study on a large sample of alcoholic beverages was provided by Jendral et al. $(n=488)$ (11). The formaldehyde concentrations of the corresponding beverage groups for all mentioned studies are summarised in Table 2. Mean concentrations of formaldehyde in a variety of alcoholic beverages ranged from $0.01 \mathrm{mg} \mathrm{L}^{-1}$ in white spirits to $0.69 \mathrm{mg} \mathrm{L}^{-1}$ in brandies. The highest concentrations were typically detected in spirits from Asia (mean $1.23 \mathrm{mg} \mathrm{L}^{-1}$ ).

Annual consumption of different types of alcoholic beverages for the population older than 15 can be easily obtained from the WHO databases. This can be done for most countries around the world. However, as studies about formaldehyde concentrations in alcoholic beverages other than European-style beverages are unavailable (especially the knowledge about Asian beverages is based on only very few analytical results), we decided to limit the whole population dietary intake estimate to the European Union (EU). The formaldehyde exposure due to alcoholic beverage consumption was calculated from Table 2 combined with values of annual per capita consumption of alcoholic beverages in the EU (see Lachenmeier et al. (14) for details on annual consumption of different beverage groups). Table 3 summarises the exposure for different scenarios.

\section{Risk characterisation}

The exposure data from Table 3 was used to characterise the risk using the margin of exposure (MOE) calculated from BMDL (Table 4). MOEs can be used by risk managers for setting priorities; small MOE represents a higher risk and vice versa. In general, an MOE of 10,000 or higher, if based on a BMDL from an animal study, would be considered a low public health concern and subsequently a low priority for risk management actions (16). In the case of formaldehyde, MOEs were in all scenarios above this 10,000 threshold, demonstrating that, in general, formaldehyde in alcoholic beverages appears not to be a public health concern.

This evaluation is in line with previous risk assessments that have considered only non-cancer end-points. For example, the WHO IPCS (2) has established a tolerable concentration (TC) of $2.6 \mathrm{mg}$ $\mathrm{L}^{-1}$ in ingested products based on the experiments of Til et al. (20). In this respect, some brandies, rum, and Asian spirits are problematic, as these products can contain formaldehyde concentrations above the threshold of $2.6 \mathrm{mg} \mathrm{L}^{-1}$ (see Table 2). However, a 60 $\mathrm{kg}$ person would need to daily consume $0.8 \mathrm{~L}$ of alcohol at $14.37 \mathrm{mg} \mathrm{L}^{-1}$ (the highest concentration found in alcoholic beverages so far) (11) to exceed the US EPA RfD of $0.2 \mathrm{mg} \mathrm{kg}^{-1} \mathrm{~d}^{-1}$ (7), which is extremely unlikely even in this worst-case scenario. None of our population-based exposure estimations exceed the US EPA RfD.

Table 3 Population-based exposure scenarios for the European Union. The table shows the formaldehyde exposure due to all types of alcoholic beverages (beer, wine, spirits, unrecorded) calculated as $\mathrm{mg} \mathrm{kg}^{-1} \mathrm{~d}^{-1}$ (calculated for a $60 \mathrm{~kg}$ person)

\begin{tabular}{|c|c|c|c|c|c|c|c|}
\hline \multirow{2}{*}{\multicolumn{2}{|c|}{$\begin{array}{l}\text { Formaldehyde exposure / } \\
\qquad \mathrm{mg} \mathrm{kg}^{-1} \mathbf{d}^{-1}\end{array}$}} & \multicolumn{6}{|c|}{$\begin{array}{l}\text { Exposure scenarios for different formaldehyde concentrations } \\
\text { in the beverages }\end{array}$} \\
\hline & & Mean & Median & \multirow{2}{*}{$\begin{array}{c}\mathbf{9 0}^{\text {th }} \\
\text { percentile }\end{array}$} & \multirow{2}{*}{$\begin{array}{c}9^{95^{\text {th }}} \\
\text { percentile } \\
3.6 \mathrm{E}-04\end{array}$} & \multirow{2}{*}{$\begin{array}{c}\begin{array}{c}\mathbf{9 7 . 5}^{\text {th }} \\
\text { percentile }\end{array} \\
4.3 \mathrm{E}-04\end{array}$} & \multirow{2}{*}{$\begin{array}{c}\mathbf{9 9}^{\text {th }} \\
\text { percentile } \\
5.3 \mathrm{E}-04\end{array}$} \\
\hline \multirow{6}{*}{$\begin{array}{l}\text { Exposure scenarios for } \\
\text { different amounts of } \\
\text { alcoholic beverage } \\
\text { consumption in Europe }\end{array}$} & Mean & $8.0 \mathrm{E}-05$ & 7.8E-06 & & & & \\
\hline & Median & $5.3 \mathrm{E}-05$ & $4.9 \mathrm{E}-06$ & $1.7 \mathrm{E}-04$ & $2.4 \mathrm{E}-04$ & $2.9 \mathrm{E}-04$ & $3.5 \mathrm{E}-04$ \\
\hline & $\begin{array}{l}90^{\text {th }} \\
\text { percentile }\end{array}$ & $1.7 \mathrm{E}-04$ & $1.7 \mathrm{E}-05$ & $5.5 \mathrm{E}-04$ & 7.7E-04 & $9.2 \mathrm{E}-04$ & $1.1 \mathrm{E}-03$ \\
\hline & $\begin{array}{l}95^{\text {th }} \\
\text { percentile }\end{array}$ & $2.0 \mathrm{E}-04$ & $2.1 \mathrm{E}-05$ & $6.5 \mathrm{E}-04$ & $9.1 \mathrm{E}-04$ & $1.1 \mathrm{E}-03$ & $1.3 \mathrm{E}-03$ \\
\hline & $\begin{array}{l}97.5^{\text {th }} \\
\text { percentile }\end{array}$ & $2.5 \mathrm{E}-04$ & $2.5 \mathrm{E}-05$ & 7.7E-04 & $1.1 \mathrm{E}-03$ & $1.3 \mathrm{E}-03$ & $1.6 \mathrm{E}-03$ \\
\hline & percentile & $2.8 \mathrm{E}-04$ & $2.8 \mathrm{E}-05$ & 8.7E-04 & $1.2 \mathrm{E}-03$ & $1.5 \mathrm{E}-03$ & $1.8 \mathrm{E}-03$ \\
\hline
\end{tabular}


Table 4 Margin of exposure (MOE) for formaldehyde in different exposure scenarios. Calculated with BMDL of $23 \mathrm{mg} \mathrm{kg}^{-1} \mathrm{~d}^{-1}$ $(M O E=B M D L /$ exposure $)$

\begin{tabular}{|c|c|c|c|c|c|c|c|}
\hline \multirow{2}{*}{ MOE } & & \multicolumn{6}{|c|}{$\begin{array}{l}\text { Exposure scenarios for different formaldehyde concentrations } \\
\text { in the beverages }\end{array}$} \\
\hline & & Mean & Median & $\begin{array}{c}90^{\text {th }} \\
\text { percentile }\end{array}$ & $\begin{array}{c}95^{\text {th }} \\
\text { percentile }\end{array}$ & $\begin{array}{c}97.5^{\text {th }} \\
\text { percentile }\end{array}$ & $\begin{array}{c}99^{\text {th }} \\
\text { percentile }\end{array}$ \\
\hline \multirow{6}{*}{$\begin{array}{l}\text { Exposure scenarios for } \\
\text { different amounts of } \\
\text { alcoholic beverage } \\
\text { consumption in Europe }\end{array}$} & Mean & 287,500 & $2,948,718$ & 88,462 & 63,889 & 53,488 & 43,396 \\
\hline & Median & 433,962 & $4,693,878$ & 135,294 & 95,833 & 79,310 & 65,714 \\
\hline & $\begin{array}{l}90^{\text {th }} \\
\text { percentile }\end{array}$ & 135,294 & $1,352,941$ & 41,818 & 29,870 & 25,000 & 20,909 \\
\hline & $\begin{array}{l}95^{\text {th }} \\
\text { percentile }\end{array}$ & 115,000 & $1,095,238$ & 35,385 & 25,275 & 20,909 & 17,692 \\
\hline & $\begin{array}{l}97.5^{\text {th }} \\
\text { percentile }\end{array}$ & 92,000 & 920,000 & 29,870 & 20,909 & 17,692 & 14,375 \\
\hline & $\begin{array}{l}99^{\text {th }} \\
\text { percentile }\end{array}$ & 82,143 & 821,429 & 26,437 & 19,167 & 15,333 & 12,778 \\
\hline
\end{tabular}

\section{DISCUSSION}

In contrast to the risk assessment of another carcinogenic aldehyde - acetaldehyde - for which a considerably lager database about human carcinogenicity and genetic epidemiology exists (14, 49), our formaldehyde assessment contains several limitations:

1. The assessment is based on only one oral animal study where formaldehyde showed specific carcinogenic effects on various tissues and organs. Some problems with the modelling of these data existed. In particular, the modelling of the data was complicated, as the background levels were relatively high. In addition, the incidence of certain carcinomas was increased in the treated groups, but the statistical power was insufficient to allow the modelling of any specific cancer site besides hemolymphoreticular neoplasias in females (see also (14) about discussion of the same problems in dose-response modelling of acetaldehyde). Additionally, there are no other estimates for BMDL and BMD values in the literature. However, as the values obtained for different endpoints corresponded well to each other and also to non-cancer endpoints from another study, we believe that the chosen BMDL value is certainly in the right order of magnitude and could be used for quantitative risk assessment.

2. The second important limitation is the fact that we assumed a uniform distribution of formaldehyde in the whole body. However, the tissues that are in direct contact with an alcoholic beverage are exposed at considerably higher levels than other organs. For example, the risk for gastrointestinal tract cancer could be higher, as stomach and intestine lesions have been reported in the animal experiments (4). On the other hand, some recent research has suggested that formaldehyde might enter the systemic circulation of humans exposed to formaldehyde (3), which would justify the application of this assumption to provide a conservative assessment until the mechanism of action has been fully elucidated.

3 . The whole population evaluation may underestimate the risk for heavy drinkers and the risk for drinkers that drink predominantly formaldehyde-rich beverages.

Besides alcoholic beverages, humans could be exposed to formaldehyde from other sources. However, the current data only allow rough estimations. Formaldehyde appears in almost all common foods at (1 to 100$) \mathrm{mg} \mathrm{kg}^{-1}$ (1) and adult dietary intake is estimated in the range from (1.5 to 14$) \mathrm{mg}$ per person per day $\left[(0.022\right.$ to 0.23$\left.) \mathrm{mg} \mathrm{kg}^{-1} \mathrm{~d}^{-1}\right]$ (1). Drinking water is expected to contain less than $0.1 \mathrm{mg} \mathrm{L}^{-1}(2)$, resulting in a daily intake of less than $0.2 \mathrm{mg}$ per person $\left(0.003 \mathrm{mg} \mathrm{kg}^{-1} \mathrm{~d}^{-1}\right)(2)$. The endogenous levels in human blood were estimated at about $2 \mathrm{mg} \mathrm{L}^{-1}$ to $3 \mathrm{mg} \mathrm{L}^{-1}$ (6). However, all of these estimates are comparably old and possibly outdated (due to regulatory changes and inadequate analytical methodologies in older studies). Migration of formaldehyde monomers from tableware was pointed 
out as a further source of food contamination with formaldehyde (50-52). This migration was estimated at ppm $\left(\mathrm{mg} \mathrm{kg}^{-1}\right)$ levels.

An important source of formaldehyde intake is cigarette smoke (2). Formaldehyde levels in mainstream smoke were reported at $45 \mu \mathrm{g}$ to $283 \mu \mathrm{g}$ per cigarette $(2,53)$. This equals a maximum exposure of $0.094 \mathrm{mg} \mathrm{kg}^{-1} \mathrm{~d}^{-1}$ for a $60 \mathrm{~kg}$ person smoking 20 cigarettes per day.

Compared with these other exposures, the average exposure via alcoholic beverages of $8 \cdot 10^{-5} \mathrm{mg} \mathrm{kg}^{-1} \mathrm{~d}^{-1}$ appears to be negligible. Nevertheless, data on cumulative formaldehyde exposure (especially for foods and beverages) are sparse and should be updated in the future.

\section{CONCLUSIONS}

The overall conclusion is that the occurrence of trace levels of formaldehyde in alcoholic beverages does not constitute an additional cancer risk for humans. Our data showed that even in worst-case scenarios, the exposure $\left(0.0018 \mathrm{mg} \mathrm{kg}^{-1} \mathrm{~d}^{-1}\right)$ is lower than thresholds of toxicity (if a threshold-based mechanism is assumed for this carcinogen, which is still a matter of debate) (54).

Our calculation has revealed that formaldehyde in alcoholic beverages shows MOEs in a magnitude that is not considered a high priority for regulatory measures. For other compounds of alcoholic beverages, such as acetaldehyde or ethyl carbamate, MOEs have been found in considerably lower ranges (below 1000) according to EFSA and Lachenmeier et al. $(14,15)$. The major risk, however, certainly comes from ethanol with a MOE of 1 or even smaller (55). Ethanol was also identified as the most important carcinogen in alcoholic beverages in a comparative quantitative assessment of 15 carcinogenic compounds (56). This study fully confirms this finding and suggests prioritising general alcohol policy measures over more specific measures such as mitigative efforts to reduce the content of trace contaminants such as formaldehyde.

\section{Conflicts of interest statement}

All authors declare that they have no direct financial interest in the subject matter or materials discussed that could inappropriately influence the manuscript.

\section{REFERENCES}

1. Feron VJ, Til HP, de Vrijer F, Woutersen RA, Cassee FR, van Bladeren PJ. Aldehydes: occurrence, carcinogenic potential, mechanism of action and risk assessment. Mutat Res 1991;259:363-85.

2. Wotld Health Organization (WHO). Formaldehyde. Concise international chemical assessment document 40. Geneva: WHO; 2002.

3. National Toxicology Program (NTP). Final report on carcinogens background document for formaldehyde. Rep Carcinog Backgr Doc 2010;(10-5981):i-512.

4. Soffritti M, Belpoggi F, Lambertin L, Lauriola M, Padovani M, Maltoni C. Results of long-term experimental studies on the carcinogenicity of formaldehyde and acetaldehyde in rats. Ann N Y Acad Sci 2002;982:87-105.

5. Baan R, Grosse Y, Straif K, Secretan B, El Ghissassi F, Bouvard V, Benbrahim-Tallaa L, Guha N, Freeman C, Galichet L, Cogliano V; WHO International Agency for Research on Cancer Monograph Working Group. A review of human carcinogens - Part F: chemical agents and related occupations. Lancet Oncol 2009;10:1143-4.

6. Wotld Health Organization (WHO). Formaldehyde, 2butoxyethanol and 1-tert-butoxypropan-2-ol. IARC Monographs on the Evaluation of Carcinogenic Risks to Humans. Vol. 88. Geneva: WHO; 2006.

7. US Environmental Protection Ageny (US EPA). Formaldehyde (CASRN 50-00-0). Integrated Risk Information System. Document 0419. Washington (DC): US EPA; 1998.

8. Penteado JCP, Sobral AC, Masini JC. Evaluation of monolithic columns for determination of formaldehyde and acetaldehyde in sugar cane spirits by high-performance liquid chromatography. Anal Lett 2008;41:1674-81.

9. Sampaio OM, Reche RV, Franco DW. Chemical profile of rums as a function of their origin. The use of chemometric techniques for their identification. J Agric Food Chem 2008;56:1661-8.

10. Lachenmeier DW, Schoeberl K, Kanteres F, Kuballa T, Sohnius E-M, Rehm J. Is contaminated unrecorded alcohol a health problem in the Europeab Union? A review of existing and methodological outline for future sdudies. Addiction 2011;106(Suppl 1):20-30

11. Jendral JA, Monakhova YB, Lachenmeier DW. Formaldehyde in alcoholic beverages: large chemical survey using purpald screening followed by chromotropic Acid spectrophotometry with multivariate curve resolution. Int J Anal Chem 2011;2011:1-11

12. Paine AJ, Dayan AD. Defining a tolerable concentration of methanol in alcoholic drinks. Hum Exp Toxicol 2001;20:5638

13. Lachenmeier DW, Haupt S, Schulz K. Defining maximum levels of higher alcohols in alcoholic beverages and surrogate alcohol products. Regul Toxicol Pharmacol 2008;50:31321.

14. Lachenmeier DW, Kanteres F, Rehm J. Carcinogenicity of acetaldehyde in alcoholic beverages: risk assessment outside ethanol metabolism. Addiction 2009;104:533-50.

15. EFSA. Ethyl carbamate and hydrocyanic acid in food and beverages. EFSA J 2007;551:1-44.

16. European Food Safety Authority (EFSA). Opinion of the Scientific Committee on a request from EFSA related to a harmonised approach for risk assessment of substances which 
are both genotoxic and carcinogenic. EFSA J 2005;282:131.

17. Kerns WD, Pavkov KL, Donofrio DJ, Gralla EJ, Swenberg JA. Carcinogenicity of formaldehyde in rats and mice after long-term inhalation exposure. Cancer Res 1983;43:438292.

18. Monticello TM, Swenberg JA, Gross EA, Leininger JR, Kimbell JS, Seilkop S, Starr TB, Gibson JE, Morgan KT. Correlation of regional and nonlinear formaldehyde-induced nasal cancer with proliferating populations of cells. Cancer Res 1996;56:1012-22.

19. Kamata E, Nakadate M, Uchida O, Ogawa Y, Suzuki S, Kaneko T, Saito M, Kurokawa Y. Results of a 28-month chronic inhalation toxicity study of formaldehyde in male Fisher-344 rats. J Toxicol Sci 1997;22:239-54.

20. Til HP, Woutersen RA, Feron VJ, Hollanders VHM, Falke HE, Clary JJ. 2-Year drinking-water study of formaldehyde in rats. Food Chem Toxicol 1989;27:77-87.

21. Tobe M, Naito K, Kurokawa Y. Chronic toxicity study on formaldehyde administered orally to rats. Toxicology 1989;56:79-86

22. Takahashi M, Hasegawa R, Furukawa F, Toyoda K, Sato H, Hayashi Y. Effects of ethanol, potassium metabisulfite, formaldehyde and hydrogen-peroxide on gastric carcinogenesis in rats after initiation with N-methyl-N'-nitroN-nitrosoguanidine. Jpn J Cancer Res 1986;77:118-24.

23. US Environmental Protection Agency (US EPA). The use of the benchmark dose approach in health risk assessment. EPA/630/R-94/007. Washington (DC): US EPA; 1995.

24. Skog E. A toxicological investigation of lower aliphatic aldehydes. I. Toxicity of formaldehyde, acetaldehyde, propionaldehyde and butyraldehyde; as well as acrolein and crotonaldehyde. Acta Pharmacol Toxicol 1950;6:299-318.

25. Trezl L, Csiba A, Juhasz S, Szentgyorgyi M, Lombai G, Hullan L. Endogenous formaldehyde level of foods and its biological significance. Z Lebensm Unters Forsch A 1997;205:300-4.

26. Cui X, Fang G, Jiang L, Wang S. Kinetic spectrophotometric method for rapid determination of trace formaldehyde in foods. Anal Chim Acta 2007;590:253-9.

27. Wang S, Cui X, Fang G. Rapid determination of formaldehyde and sulfur dioxide in food products and Chinese herbals. Food Chem 2007;103:1487-93.

28. Bianchi F, Careri M, Musci M, Mangia A. Fish and food safety: Determination of formaldehyde in 12 fish species by SPME extraction and GC-MS analysis. Food Chem 2007;100:1049-53.

29. Lawrence JF, Iyengar JR. The determination of formaldehyde in beer and soft drinks by HPLC of the 2,4dinitrophenylhydrazone derivative. Int J Environ Anal Chem 1983;15:47-52.

30. de Oliveira EA, de Andrade JB. Simultaneous determination of formaldehyde and acetaldehyde and their respective hydroxyalkylsulfonic acids by HPLC. Quimica Nova 1994;17:13-6.

31. de Andrade JB, Reis JN, Rebouças MV, Pinheiro HLC, Andrade MV. Determination of formaldehyde and acetaldehyde in drinking water and alcoholic beverages by high performance liquid chromatography (HPLC). Quimica Anal 1996;15:144-7.

32. Nascimento RF, Marques JC, Neto BSL, De Keukeleire D, Franco DW. Qualitative and quantitative high-performance liquid chromatographic analysis of aldehydes in Brazilian sugar cane spirits and other distilled alcoholic beverages. J Chromatogr A 1997;782:13-23.

33. Ebeler SE, Spaulding RS. Characterization and measurement of aldehydes in wine. In: Waterhouse AL, Ebeler SE, editors. Chemistry of wine flavor. Washington (DC): American Chemical Society; 1998. p. 166-79.

34. Lau MN, Ebeler JD, Ebeler SE. Gas chromatographic analysis of aldehydes in alcoholic beverages using a cysteamine derivatization procedure. Am J Enol Vitic 1999;50:324-33.

35. Wardencki W, Sowinski P, Curylo J. Evaluation of headspace solid-phase microextraction for the analysis of volatile carbonyl compounds in spirits and alcoholic beverages. J Chromatogr A 2003;984:89-96.

36. Burini G, Coli R. Determination of formaldehyde in spirits by high-performance liquid chromatography with diode-array detection after derivatization. Anal Chim Acta 2004;511:1558 .

37. Curylo J, Wardencki W. HS-SPME-CGC-PID determination of aldehydes in rectified spirits and vodkas after derivatisation with 2,4,6-trichlorophenylhydrazine (TCPH). Chem Anal (Warsaw) 2005;50:735-48.

38. Anonymous. Chinese brewing industry defend use of formaldehyde. Modern Brewery Age 2005 July 18

39. Rodríquez DM, Wrobel K, Wrobel K. Determination of aldehydes in tequila by high-performance liquid chromatography with 2,4-dinitrophenylhydrazine derivatization. Eur Food Res Technol 2005;221:798-802.

40. Sowinski P, Wardencki W, Partyka M. Development and evaluation of headspace gas chromatography method for the analysis of carbonyl compounds in spirits and vodkas. Anal Chim Acta 2005;539:17-22.

41. Curylo J, Wardencki W. Application of single drop extraction (SDE) gas chromatography method for the determination of carbonyl compounds in spirits and vodkas. Anal Lett 2006;39:2629-42.

42. Park YS, Lee YJ, Lee KT. Analysis of formaldehyde and acetaldehyde in alcoholic beverage. J Korean Soc Food Sci Nutr 2006;35:1412-9.

43. Wu QJ, Lin H, Fan W, Dong JJ, Chen HL. Investigation into benzene, trihalomethanes and formaldehyde in Chinese lager beers. J Inst Brew 2006;112:291-4.

44. de Oliveira FS, Sousa ET, de Andrade JB. A sensitive flow analysis system for the fluorimetric determination of low levels of formaldehyde in alcoholic beverages. Talanta 2007:73:561-6.

45. Miyakawa H, Fujinuma K, Kamata K. Determination of formaldehyde in beer. Ann Rep Tokyo Metropol Inst Public Health 2007;58:185-8.

46. Elias RJ, Laurie VF, Ebeler SE, Wong JW, Waterhouse AL. Analysis of selected carbonyl oxidation products in wine by liquid chromatography with diode array detection. Anal Chim Acta 2008;626:104-10

47. Zhao XQ, Zhang ZQ. Microwave-assisted on-line derivatization for sensitive flow injection fluorometric determination of formaldehyde in some foods. Talanta 2009;80:242-5.

48. Zhao XQ, Zhang ZQ. Rapid and sensitive determination of formaldehyde in some beverages and foods by flow-injection fluorimetric analysis. Int J Food Sci Technol 2009;44:21621. 
49. International Agency for Research on Cancer (IARC) Acetaldehyde. IARC Monographs on the Evaluation of Carcinogenic Risks to Humans. Vol. 71. Lyon: IARC; 1999.

50. Lund K, Petersen J. Migration of formaldehyde and melamine monomers from kitchen- and tableware made of melamine plastic. Food Addit Contam 2006;23:948-55.

51. Bradley EL, Boughtflower V, Smith TL, Speck DR, Castle L. Survey of the migration of melamine and formaldehyde from melamine food contact articles available on the UK market. Food Addit Contam 2005;22:597-606.

52. Ishiwata $\mathrm{H}$, Inoue $\mathrm{T}$, Tanimura $\mathrm{A}$. Migration of melamine and formaldehyde from tableware made of melamine resin. Food Addit Contam 1986;3:63-70.

53. Wong JW, Ngim KK, Shibamoto T, Mabury SA, Eiserich JP, Yeo $\mathrm{HCH}$. Determination of formaldehyde in cigarette smoke. J Chem Educ 1997;74:1100-3.
54. Appel K, Bernauer U, Herbst U, Madle S, Schulte A, RichterReichhelm H, Gundert-Remy, U. Kann für Formaldehyd eine "sichere" Konzentration abgeleitet werden? - Analyse der Daten zur krebserzeugenden Wirkung [Can a "safe" concentration be established for formaldehyde? - Analysis of carcinogenicity data, in German]. Forsch Prax 2006;11:34761.

55. Lachenmeier DW, Kanteres F, Rehm J. Epidemiology-based risk assessment using the benchmark dose/margin of exposure approach: the example of ethanol and liver cirrhosis. Int J Epidemiol 2011;40:210-8.

56. Lachenmeier DW, Przybylski MC, Rehm J. Comparative risk assessment of carcinogens in alcoholic beverages using the margin of exposure approach. Int J Cancer 2012, DOI: 10.1002/ijc.27553. 


\section{Sažetak}

\section{GRANICA IZLAGANJA FORMALDEHIDU U ALKOHOLNIM PIĆIMA}

Formaldehid je kancerogen za ljude te je klasificiran u skupinu 1 prema WHO IARC-u. Uzrokuje leukemiju i nazofaringealni karcinom, a navodi se i kao redoviti sastojak alkoholnih pića. Međutim, rizik od izlaganja formaldehidu konzumacijom alkoholnih pića nije sustavno istražen pa će ovo istraživanje pružiti prvu takvu procjenu rizika. Količina formaldehida koju ljudi unose alkoholnim pićima u Europskoj je uniji procijenjena temeljem podataka Svjetske zdravstvene organizacije o konzumaciji alkohola i literature o sadržaju formaldehida u različitim skupinama alkoholnih pića (pivo, vino, jaka alkoholna pića i neregistrirani alkohol). Procjena rizika obavljena je korištenjem pristupa granice izlaganja (eng. margin of exposure, MOE) i graničnih doza (eng. benchmark doses, BMD) za $10 \%$-tni učinak koji se postiže modeliranjem odnosa doza-odgovor $\mathrm{u}$ ispitivanjima provedenima na životinjama. BMD od $30 \mathrm{mg} \mathrm{kg}^{-1}$ tjelesne težine na dan i BMD s nižom granicom pouzdanosti (BMDL) od $23 \mathrm{mg} \mathrm{kg}^{-1} \mathrm{~d}^{-1}$ izračunati su za tumore kod mužjaka štakora temeljem raspoloživih dugotrajnih ispitivanja provedenih na životinjama. Prosječno izlaganje ljudi formaldehidu u alkoholnim pićima procijenjeno je na $8 \cdot 10^{-5} \mathrm{mg} \mathrm{kg}^{-1} \mathrm{~d}^{-1}$. U usporedbi s BMDL vrijednošću krajnji MOE je iznosio više od 200.000 u prosječnim situacijama. Čak i u najlošijim situacijama MOE nije nikada bio niži od 10.000, što se smatra graničnom vrijednošću za zdravlje ljudi. Procjena rizika pokazuje da je rizik od nastanka karcinoma uslijed izlaganja formaldehidu iz alkoholnih pića zanemariv te da je prioritet upravljanja rizikom u takvim slučajevima (npr. kako bi se smanjila kontaminacija) vrlo nizak. Najveći rizik proizlazi iz etanola i acetaldehida koji se također nalaze u alkoholnim pićima.

KLJUČNE RIJEČI: alkohol, aldehidi, karcinom, konzumacija alkohola, procjena rizika

\section{CORRESPONDING AUTHOR:}

Dirk W Lachenmeier, PhD

Chemisches und Veterinäruntersuchungsamt (CVUA)

Karlsruhe, Weissenburger Strasse 3, D-76187 Karlsruhe, Germany

E-mail: Lachenmeier@web.de 